\title{
VOYEURISM, ETHICS, AND THE LURE OF THE EXTRAORDINARY: LESSONS FROM STUDYING AmERICA's Underground
}

\author{
Kathleen Blee \\ University of Pittsburgh \\ PREPARED BY \\ BRITTANY HANSTAD AND AISLINN ADDINGTON
}

Joane Nagel: Welcome to the $8^{\text {th }}$ Annual Clark Lecture, sponsored by the Sociology Department here at the University of Kansas where we bring in a sociological luminary to spread the word about the sociological perspective and to, we hope, illuminate some things about what is going on in contemporary society. The Clark Lecture was established with an endowment gift from Pauline Ebstein Gardside in honor of Dr. Carol Clark who was a longstanding member of the sociology department from 1930 to 1968, chairing the department for many of those years. Ms. Gardside was a student of Dr. Clark. Our Clark Lecture this year is Professor Kathy Blee from the University of Pittsburgh. She is not only a distinguished scholar; she is a fine teacher and academic leader. I don't want to use the word administrator, so many people shame under that name, although I've certainly served in that role. So, Kathy, when I met her in 1999 when I visited Pittsburgh, she was chairing the Women's Studies program - she was in the Sociology department there - she's since ducked the bullet of chairing the sociology department, at least for the moment, but she's also served as an associate Dean when she was at the University of Kentucky before

Parts of this talk have been published in Inside Organized Racism: Women in the Hate Movement (University of California Press 2002); "Managing Emotion in the Study of Right-Wing Extremism." Qualitative Sociology 21 (December, 1998):381-399; and "Studying the Enemy" In Barry Glassner and Rosanna Hertz (eds.), Our Studies, Ourselves. (Oxford University Press 2003):13-23. 
she went to Pittsburgh. Kathy has spent most of her intellectual scholarly life thinking about what she refers to as the "paradoxes of class, gender, and race," in the United States. Her work has also spanned U.S. borders. Her best known book, but there are a couple of others that will become best-known I'm sure in the future, is, Women of the Klan: Racism and Gender in the 1920's, where she examined how the $\mathrm{Ku}$ Klux Klan was able to mobilize millions of men and women in its racist crusades by claiming to represent the interests of women's rights and family values. I remember her once telling a story about some follow up field work that she did as a part of that whole long project that extends into the present, where she was in the woods with some Ku Klux Klan racist members and they were burning a giant cross and she was worried that they and she were all going to die together and that the cause of field work might end up being greater than she anticipated. I want to say that her work is very courageous and adventurous. The people she was studying knew she was a social scientist, but she has paid a price for doing that kind of research in terms of having to live with the consequences of it.

She is also right now working on, Inside Organized Racism: Women and the Hate Movement. She broadened her research beyond just the Klan, into Skinheads, Nazis, and Right Wing Fascist movements in general. And she also has a history of studying class, not just race, looking at Appalachia and counties that used to be very, very prominent and successful and how they became among the poorest in the United States. In closing I'll say Kathy is involved in two projects right now. One is funded by the National Science Foundation in the study of new social movements, how to track the movement before it actually becomes a movement. She is actually reading about and working with some groups in Pittsburgh as they become emerging movements. She wants to see which ones survive and which ones don't. And she is also working on a project on racial violence that does not appear in institutional statistics - I'd actually like to hear how you get the numbers in there. So, I am pleased and honored to introduce Professor Kathy Blee, who will deliver this year's Clark Lecture, "Voyeurism, Ethics, and the Lure of the Extraordinary: Lessons from Studying America's Underground." 
Kathy Blee: Thank you very much. Let me tell you it's great to be back in Lawrence. I was here a while ago working on this last book and looking at the extraordinary collection of Right-wing material that is in the Wilcox collection in the library here. Lawrence is just as nice as I remember, and just as hot as I remember. I want to thank Joane Nagel for arranging this visit. And Joey Sprague and the Sociology Department for their kind invitation, and a very stimulating visit to the department.

So, like Joane said, I've spent the last 20 years or so studying the racist underground, reading its vile literature, listening to its leaders and rank and file relate its vicious ideas, and trying to understand why otherwise normal and average people can be attracted to the crusade to destroy Jews, people of color, feminists, those who work for ZOG (Zionist Occupation Government), people, that is, like me and most of you. The day I came back from observing my last — and I really hope it is my last - Ku Klux Klan rally, I had a meeting with a graduate student. She had just returned from the Highlander Center in Tennessee, where she had attended a conference of consumer activists, who were cementing a trans-Atlantic alliance against the abuse of the mentally ill by psychiatrists and psychiatric institutions. She was exhilarated, brimming with feelings of empowerment that she had felt all around her. And eager to give voice to the stories and sentiments of those patients' rights activists.

In contrast, my trip left me feeling, at best, numb. What I wanted to do was not to remember, to bury what I had seen rather than proclaim it. It was almost a year before I could bring myself to even open my notes on that rally, sheets of paper, to which faint scents of smoke and kerosene seemed to cling. If my student wanted to gather people together to hear her stories, I found myself very cautious about talking about my research — worried that I would be sullied by the political stigma attached - rightfully, of course - to the racist groups that I studied.

I am not alone in this dilemma. Earlier feminist scholarly efforts to celebrate women's accomplishments, to unearth the varied history and the present of women's agency and leadership and insight, is being replaced by a different kind of scholarship, one that pays 
close attention to how exclusionary practices, and ideas beyond those of gender - practices and ideas of racism, and colonialism, and heterosexism, and xenophobia, etc. have shaped the opportunities and constraints of groups of women so radically differently, dividing women along axis of race, social class, citizenship status, sexuality, household status, region, employment status, and many, many other factors.

A decade ago, much feminist scholarship applauded the tenacity of women who challenged the limits of their assigned social positions and who exposed the invisible rules of gender that governed their lives. But now, we're more likely to be unveiling problematic layers of women's lives and women's histories, revealing the racist subtexts, the repressive sexual agendas, and the nationalistic and xenophobic impulses behind many women's collective projects, even those with aspects that we might want to celebrate. Can we think of the United States women's suffrage movement now without acknowledging that some of its most prominent leaders found common ground with reactionary and racist Southern politicians? [By the way, many of the leaders of the women's Ku Klux Klan in the 1920 's had earlier been women's suffrage leaders.] Can we acclaim those women who fought for the rights for married women to own property and gain custody of their children without also pausing to consider how these victories came at the expense of delegitimating alternative family arrangement? Can we applaud Victorian Europe's intrepid women travelers who made their way across continents of Africa, Asia, and Latin America, without also remembering their complicity with the most exploitive colonial agendas? And, can we celebrate women's ascent into political leadership without noting the militaristic and anti-social welfare policies promoted by recent female heads of state and secretaries of state?

The answer of many scholars of sociology and other disciplines of today is that, no, we cannot ignore these awkward and difficult, but illuminating complexities. So many researchers - besides me- spend their time probing unsavory aspects of women's history and women's experience. Another way of thinking about this change is that we've replaced the scholarship of heroism with one that is sharper, more critically edged, more inclusive, but also 
sometimes a lot less fun to write. For many of us, disappointment has replaced exhilaration in our work.

My studies of the Klan, Neo-Nazis, and White Power Skinheads, certainly puts me on the edge-or I'm sure some people might argue, over the edge - of what I sometimes call the "underbelly of scholarship." Might my experiences researching the racist underground, charting its recruitment of women and teenagers and its plans to enact racial terror and apocalyptic race war, also provide a way of thinking about some difficult issues that plague those doing less unsavory, and no doubt much more fun, kinds of scholarship?

In this talk I want to consider four dilemmas that have occurred in my work, and perhaps occur more broadly in feminist and sociological research. These are, first of all, the dilemma of separating the mundane from the extraordinary. Secondly, the emotional work of scholarship. Third, the dynamics of voyeurism and seduction. And finally, the question of for whom we speak?

So, first the question of the mundane and the extraordinary. To think of this particular tension, let's return for a minute to the Klan rally, the one I said I didn't want to talk about, but now I will. To set the context of this event. I ended up at this rally site by following the directions that were given to me over the phone by a Klan leader who I had known for many years. The directions were a prize, as it were, bestowed on me after years spent negotiating my entrée into his Klan world. Following his directions took me from a tiny town in the middle of nowhere down a 10-mile dirt road and then up a long driveway festooned with swastikas and Klan banners. When I arrived that morning, the rally was gearing up. Skinheads, Klan members, and other assorted Neo-Nazis had come together for a day of their common evil purposes. As always at these events, speeches and conversations revolved around the issue of enemies. The idea of an enemy forges bonds of common hatred among people who might otherwise find little in common. Here were young skinhead men covered with swastika tattoos sitting next to middle-aged Klan women cradling small children and chatting together amicably about the dangers of hidden Jews in government or the growing threat they saw posed by Hispanic immigrants. Collective rhetoric 
against enemies in this kind of organized racism can be intricately choreographed as its leaders create a verbal crescendo in their speeches, calling for violence and death for enemy groups.

The talk about enemies also can be chillingly casual, a point of interpersonal connection as incidental as discussions of the weather might be the strangers at a cocktail party. During this rally, Frank, a skinhead from Texas, sidled up to me to share his disgust at an event he described as so mild it was, "something you could see on the Family Channel." At his side, a Nazi named Susan echoed his sentiment, complaining that she felt trapped in a "Baptist church social." We chatted some more. Frank boasted that this was nothing like he expected. He made this long trip to "get his juices going," not to be part of something that had been concocted by wimps. Susan agreed, pointing with disdain to a group of women hauling boxes of hamburger buns over to a large grill.

Now how could that be? To me, the scene was horrifying, anything but mundane, as they were describing it. For one thing, Frank's arms were covered with swastika tattoos; on his head was a baseball cap with a comic-like depiction of an African-American man being lynched. Susan's black skirt, hosiery, and boots accentuated the small Klan cross embroidered on her white tailored shirt. And certainly the rituals of historical hatred being enacted in front of us seemed far from what they described as "disappointingly tame." A cross was doused with gasoline and set ablaze, people spoke casually of a need to "get rid of African-Americans, immigrants, Jews, gay men and lesbians, Asian-Americans." And they exchanged historical trivia that purported to expose the Holocaust as a Zionist hoax.

Only much later did I come to understand how Frank and Susan could compare such a racist rally to a community social gathering. With some time and some psychic distance from Frank and Susan and others like them, I came to see that aspects of racial gatherings do mirror church socials or neighborhood picnics, albeit in a distorted and perverse fashion. I remember a card table piled high with racist children's books, bumper stickers, and index cards of White Power recipes, sessions on self-help for disgruntled or substanceaddicted members, hymns sung as background to speeches about 
strengthening the racialist movement, and the pancake breakfast and social hour that followed.

Indeed much of racist groups appears disturbingly ordinary, especially its evocation of community family and social ties. It's this ordinariness of racism that we see in Aryan weddings, where white, lace dresses and black tuxedos come embroidered with swastikas and rest on steel-toed boots. The awesome power of culture to normalize racism is evident in an account of a gathering of 400 Neo-Nazis in Idaho, which a visiting journalist from a mainstream paper described in her report as, "so benign . . . everyone was so common, so average, so mannerly, and nice."

Even some of the ideas of organized racism can seem unremarkable, as evident in the scary bridge between mainstream conservatives and racist groups that can sometimes, though not often, be created by issues like opposition to gun control. But the watershed that separates racist activism from the rest of society is as striking as the similarities. The beliefs of people in racist groups are not just extreme variants of racism or xenophobia or anti-Semitism as they are often described. Rather, there's a logic of conspiracy, an absolute zeal, and a passion for activism that separate members of these racist groups from those in the "alien world" as they describe it, the outside, the rest of us. Those who become invested in these groups learn what they come to regard as "the truth" about, for example, Jewish conspiracies and, as the prize for their commitment, as a ticket they earn over time, they learn from these groups so-called "secrets" that the rest of us, in alien society, don't know. They "learn" that Jews invented the Holocaust to reap financial and political benefits for the state of Israel. They "learn" that Jews are the literal, biological descendents of Satan, as in the belief of Christian identity. And that Jews manipulate racial antagonism between white Aryans and peoples of color for their own benefit, to usher in a Jewish-dominated one-world order. And they come to believe that this omnipotent but completely invisible group of Jews control every detail of one's life. Jews can, and they do, these people believe, have the ability to make you sick, cause your husband to beat you, and control your mind so you fail your math test. It's this combination of the average and the ordinary, 
the peculiar and the prosaic that counts for much of the resilience of these racist groups.

This same clash of the ordinary and the extraordinary showed up in my earlier research on the 1920s Klan. The elderly former Klan members I interviewed late in life, long after the 1920's Klan collapse, almost never seemed to appreciate why they might be viewed as having been intolerant or bigoted, except when they were defending against the historical condemnation of subsequent generations, like my own. They felt no need even to explain why they found the Klan appealing. To them, in the 1920s, life in the Klan was normal, a given, something that needed no explanation. The only puzzle to them was why people like me regarded their Klan so negatively.

Those kinds of mundane reactions have value. They reveal, but they also conceal, the force and fear of this Klan. In many parts of the U.S. in the 1920's, primarily in the Midwest and the North, the $\mathrm{Ku}$ Klux Klan so dominated communities in which white Protestants were the majority that Klan life became inseparable from non-Klan life. With its myriad of Klan orchestrated weddings, Klan dating, Klan christenings, Klan teenage auxiliaries, Klan family picnics, Klan baseball leagues, Klan parades, spelling bees, beauty contests, rodeos, and circuses, it's little wonder, perhaps, that the 1920's Klan is recalled by its former members as such an ordinary, normal part of taken-for-granted life, of the white, Protestant majority.

For its members, life in the Klan defined the very fabric of everyday life, reinforcing and dictating their relations of kinship and friendship, their practices of celebration and sorrow. In the minds of its members, even after all that time, the Klan was understood as little more than "just another club." The political culture and activities of this Klan so closely paralleled the lives of the former members I interviewed that they could tell me without a drop of irony things like, "everyone was in the Klan," or, "it was a fun organization like a Halloween parade — we'd mask up, wear sheets and be entertained."

This also led to eerily abstracted and contradictory statements, like a woman who insisted to me that, "the one Jewish merchant in town, well, he became part of the community. I don't think anyone 
ever thought about doing anything to him, but, of course, people didn't go to his store." A political movement like the Klan could call for, in their words, "putting all the Catholics, Jews, and negroes on a raft in the middle of the ocean and then sink the raft," but still be remembered by its former members as an ordinary, unremarkable social club to this day. Hannah Arendt's notion of the "banality of evil" is found here, in the millions of people who joined an extraordinary crusade of violent hatred so easily, so unreflectively, and for such mundane reasons.

Now someone with better foresight than mine in selecting their research topics is unlikely to confront this particular muddle of the mundane and the extraordinary, but the connection between these underlies many kinds of sociological and feminist research. Indeed one object of feminist scholarship has been to explore the extraordinary nature of what is constructed as ordinary, to see how daily life practices like mothering, feeding a family, neighborhood socializing, and maintaining connections with kin, can comprise a foundation upon which radical transformations of the world have taken place.

In this way, we give importance to matters that are often dismissed as trivial. But work like mine, on the underbelly of women's history and politics, reminds us to go the other way as well, to consider the mundane qualities of extraordinary events, to think about the myriad, and in themselves, uneventful happenstances, the unremarkable practices, ideas, and motivations, that constitute the events of social life and social history.

Secondly, I want to deal with the emotional work of scholarship. Studies like mine prod us to think about the emotional work that goes into our studies and scholarship. Of course this is because the emotional work of studying organized racism is raw and on the surface. It is not easily ignored and is not readily amenable to being a detached scholar. But surprisingly, feminist approaches to scholarship, although highly attuned to the emotional dynamics of those we study, provide less guidance than might be expected about the emotional work of studying the underbelly of scholarship.

In part this reflects early feminist dictums to respect the truth of people's individual experiences, to preserve the integrity of ordi- 
nary people's lives who we study, and to seek what the sociologist Judith Stacey calls, "an egalitarian research project, characterized by authenticity, reciprocity, and intersubjectivity between the researcher and her subject." Those kinds of practices of empathy work well for many studies - especially of people we like, like union organizers and Civil Rights workers - and others with whom we find common experiences and whose life stories and world views are understandable, at least in part. However, principles that serve well for studying people we're sympathetic with can prove immobilizing with less attractive subjects. Would it even be possible, to say nothing of desirable, to strive for an empathetic connection, an authentic exchange, or rapport with a member of the Klan? It's one thing to try to understand the world through the eyes of someone for you whom you have some sympathy, but a very different matter to think about developing an emotional tie to a racist activist whose life is given meaning and purpose by the desire to annihilate you and others like you. Moreover, even if it were possible, those feelings violate expected boundaries between scholars and those who are characterized - in great understatement - as "unloved."

Thinking about these things makes us consider the emotional work, that like housework, is the un-ending, but invisible, substructure of our studies and our scholarship. The emotional shock of being immersed with Nazis and Skinheads are clear. The scholarly burn-out in this area of work is very high. But there is a quite similar emotional undergirding in all scholarly work that we are often too involved to admit. My experience in working in the scholarly underbelly suggests that it might be better for all of us to consider and to talk with each other as scholars and students about how our entanglements with those who we study - alive or dead - generate feelings in us, feelings of disappointment, excitement, of anger, exhilaration, and of resentment. It suggests that we need to acknowledge the emotional toll as well as the occasional psychic boost that we experience in our work as students and scholars.

Thirdly, I turn to questions of voyeurism and seduction, which I think are even more vexing emotional complexities in this kind of research. Here I want to take us back to the extreme underbelly 
of my studies of organized racism. Although difficult to acknowledge, it is true that interviewing members of racist groups, many of whom are "semi-underground" or certainly on the political margins, while often scary and always unsettling, also is intriguing and even voyeuristic. Meeting racist activists, I'm embarrassed to admit, can be exciting as well as horrible, a fill of titillating experiences and fodder for stories like those I have told you here. Sociologist and ethnographer Barrie Thorne captures this sense of field work as adventure very well, describing it as, "venturing into exciting, taboo, dangerous, perhaps enticing social circumstances, getting the flavor of participation, living out moments of high drama, but in some ultimate way, having a cop out, a built in escape, a point of outside leverage that full participants lack."

It's not hard to see how sitting around with people who talk about murder as casually as we might talk about the weather, or how being led out in the countryside to see a cache of weapons that have been sequestered for an imminent race war could enlist an unsettling mixture of abhorrence and fascination. In this sense racist groups are another form of "the Other", captivating in their abhorrence, their seeming distance from the assumed and the known. But the voyeurism of studying these kinds of hate groups has at least muted parallels in other kinds of scholarly work. We need to think hard about our approach to those whom we widely research, those that we bring into view with our scholarship. We need to wonder honestly and often whether elements of titillation guide our selections of topics and subjects, even a little bit. And we need to ponder how it might be possible to peer into someone else's life, or writing, or body, without being at least a little voyeuristic.

Tied to voyeurism, kind of its opposite, but also its twin, is the problem of seduction. If voyeurism comes from a psychic distancing, the experience of scholarly seduction, as the anthropologist of Argentinean-Fascism Antonius Robben notes, "Seduction trades our critical stance as observers for an illusion of congeniality with cultural insiders." Indeed, like others who have studied loathsome political groups, it is a painful discovery to find how charming and engaging participants in some of history's most dreadful events can be. 
My time with Linda, a White Power Skinhead from the West Coast, illustrates one outcome of emotional seduction. Before I sat down to interview Linda, things with her were, to put it mildly, tense. With every phone call she insisted on changing the place and conditions of the interview, demanding more and more evidence that I wasn't with the police, and threatening to bring her boyfriend and a gun to the interview - in violation of what I thought was our agreement. Each demand required more negotiation and gave Linda yet another opportunity to remind me that she would not hesitate to hurt anyone - like me - who betrayed her or her group.

In this case there was ample reason to take Linda's threats seriously, as I discovered that both Linda and the boyfriend (who she threatened to bring to the interview) had just recently been released from prison, where they had served sentences for assault, drug sales, and other offenses. So I came to the interview frightened and prepared for a very hostile conversation, which was how things had gone up until that point. In person, however, Linda was the opposite of my expectations. She was charming, soft spoken, and concerned for my comfort during the interview. Although quite willing to express her most appalling ideas, Linda prefaced many of her statements by apologizing that I might find what she was about to say offensive. My fear eased away, replaced by a seductive and false rapport, in which Linda set the parameters and I responded. Caught off guard in that way, I pressed Linda less intensely than I did other women to explain contradictions in her story and her logic. In retrospect - through reading the transcript afterwards - I am uneasy about the notes I wrote immediately after the interview. They show how disarming the subversion of expected emotion can be, even when you are suspicious of it. Like one note that characterized Linda as, "extremely cordial and very friendly, not trying to intimidate me in any way." What was I thinking? The hazards of that kind of seduction, not unlike the hazards of voyeurism, should make us reflect hard on our entanglement with those we study.

And finally I want to talk about the issue of consequences. Closely related to the dilemma of empathy are the ethical issues of gathering oral and life histories of Klan members and others in the racist underground. Too rarely do we question the value of our 
scholarship beyond the academy. This is particularly true, oddly enough, even of feminist scholarship, which is often viewed as inherently harmless, and more often liberatory to those who are its subjects. Indeed, much feminist work was born with a vision of understanding the world from the bottom up, through histories that seek to empower contemporary groups with authentic accounts of the lives and struggles of their forefathers, or contemporary accounts of the embattled but resilient third world communities battling the forces of globalization or environmental degradation.

Sociology, too, emerged through the ideals of early $20^{\text {th }}$ century scholars, many of them socialists, who wanted to understand the situation of the poor, the victimized, and the displaced in order that those situations might be improved. To return to an earlier point, it's clear that people try to make sense of the events of their lives by placing them in narratives or storylines, like those earlier Klan people did. Is it not possible, then, that oral histories, for example, might help those I studied construct a narrative that makes sense of themselves and the Klan and its actions?

After interviewing a female German Nazi leader, the historian Claudia Koonz reflected, "I realize I had come to get information and she intended to give me a sanitized version of Nazism that would normalize the Hitler state in the minds of contemporaries. She saw the chance to share her views with an American as a way of taking her message to not only a younger generation but a new audience."

Feminist scholars insist that a researcher cannot be content with merely recording another's life story for scholarly publication, but must return the research to the subject as a means of empowering them in their community, and thereby trying to reduce the inherent inequality between researcher and subject. But is this ethical principle based on romantic assumptions about the consequences of fortifying the political agendas of ordinary people? Does this principle serve any purpose, for example, in histories of the Klan?

This is an issue I think for which there is no easy solution. It seems obvious that researchers should not actively seek to empower people like the Klan, but is it possible that the very nature of this research, the process of eliciting and conducting interviews with 
Klan members and Nazis, is itself empowering by suggesting to them and to their political descendents their importance in American history?

I was initially surprised and later deeply disturbed to find that many of the racist activists I met have copies, sometimes multiple copies, of my book. Of course they don't agree with my analysis or my conclusions, but they see being studied as inherently validating. It's important to understand the racist underground, to study how it's able to attract ordinary and not particularly racist and not particularly disturbed teenagers, for example, and turn them into racial zealots who want to fight off the collapse of the white race. Such knowledge can be useful in the struggle against organized racism. For example, one of my findings that women racists, but not men, tend to maintain a secret contact with a sister or friend from the alien world, has been used by anti-racist groups to create a safe passage out of racist groups for some of its disaffected female members. But also there's a decided risk to this kind of work that needs to be acknowledged. The hazard of empowering a political vision of racial and religious hatred is painfully clear.

These ethical and political dilemmas, although they're obviously extreme, suggest a broader need to think seriously about the sometimes murky consequences of our studies, about who benefits from them as well as who might be hurt, who is potentially empowered and who is potentially disempowered. Many of us struggle to reconcile the demands of our scholarly school careers with our commitment to libratory social change. But we need to go beyond that and consider whether and how our work, our scholarship, our writing, moves the world in the direction we want it to go. We need to figure out ways to allow ourselves the pleasure of intellectual inquiry, but without forgetting that our work makes a mark in the world, and that we are responsible for that mark.

Now, as often is the case, the words of a poet, Marge Piercy, captured the burden and pleasure of acknowledging the place of our work in the larger world much more eloquently than I could. I want to close with a few lines from her work, a poem called "To Be of Use." 
I love people who harness themselves, an ox to a heavy cart, who pull like water buffalo, with massive patience, who strain in the mud and the muck to move things forward, who do what has to be done, again and again.

The work of the world is common as mud.

Botched, it smears the hands, crumbles to dust.

But the thing worth doing well done

has a shape that satisfies, clean and evident.

Thank you.

Joane: Thank you Kathy. I think it's time for some questions.

Audience: Did the people you interviewed believe you were on their side? Through the course of your interaction did you feel they were trying to convince you to believe in their way of life?

Blee: No, they never did. This initially surprised me because I didn't realize that they had read my earlier work. But in fact they had and they knew where I stood. So, rarely did people challenge me or say, "We don't like what you said." I never purported to be positive about them. Because these groups are so marginal, however, they don't see that as very problematic. Everybody is different from them and everybody's beliefs are quite contrary to theirs so they don't find that particularly surprising. I promised to be fair and accurate but I never said I would be positive or anything like that. So, rarely did we get into that kind of tussle. The other thing is that in this project I didn't ask them much about their ideas. For one thing, we already know what their ideas are. Who wants to hear the same ridiculous, vile, poisonous stuff all over again? And it's not even that interesting, because racist activists tend to act like parrots if asked what they believe: they just say something they have memorized. What I was more interested in was how they got into racist groups and how they came to those beliefs. So I didn't elicit their beliefs. When they would start down that train of thought, I would pretty stop them by saying, "Ok, well, that's fine, but what about ..." 
Audience: How did you deal with interviewing and interacting so closely people that under normal circumstances you wouldn't like?

Blee: I expected not to like them, of course. But, it was disturbing to find that I came to like - or, rather, feel empathy toward - some of them on a personal level. Them, not their ideas or actions. And these were people whose beliefs included wanting to kill people like me.

It is difficult to use some ethnographic principles when studying racist groups. For example, if I was interviewing anybody else, if they said something about their family, I would be likely to respond with something about my family, to establish rapport. But I'm not going to talk about my family with racist activists. The ethnographic principles of reciprocity, giving back, making a connection, being human - rules that not only make good Sociology but good human values - are quite difficult to follow in this kind of research. So I ended up falling back on much more 1950's style of interviewing where I act like a recording machine. Not completely, but certainly more than I would do in another situation. And it's very difficult to keep a conversation going when you don't give anything back to the respondent. Like you guys are doing, keeping me talking because you're nodding at me. Well, in an interview, I'm not going to nod when I am listening to someone spew a bunch of racist garbage. I'm not going to say, "Oh yeah." Instead, I just sat there like a deer in the headlights, saying "Ok, well, onto the next question." The only other thing I would say is, and this isn't a principle, just a product of growing up in the Midwest, I think I came across as unthreatening to them. I think they felt like they could say things and I wasn't going to yell at them back.

Audience: I'm curious, when you're operating in a participatory research mode, and you're identifying with the others, you're one of the group, might there be blinders there? In a kind of limited playing the role of the other that it has really bad consequences in the sense that you aren't really amplifying ambiguities or contradictions that might be problematic in their politics?

Blee: Oh absolutely. I totally agree. In this research, it hit you in the face, but it exists elsewhere too. There has been very good feminist writing about how the most exploitive ethnographic work 
can be feminist work where you encouraging people to tell their stories. Is it ethically and politically and morally always right to ask people to spill their guts for your research? We tell people that "we're not going to use your name", but we don't always know what the consequences of our studies might be for those we study. And certainly they don't either. This actually occurred to me first when I did this work on the 20's Klan. The people I interviewed were old, very old. Many were in their 80 's and 90's. I told them that I'd keep their names out of the study, which I did. But they didn't think it was necessary. They were so distant in age and experience from the process of academic research that they had no idea what it would have meant to have their name published in such a book. They had no way to imagine how it would affect their children or grandchildren. So, although we get caught up in technical ethics, it's also important to look down the road and see what our informants cannot.

Audience: I'm curious, and I know you probably won't disclose the location, but I grew up in a very small town not too far from here that was rumored to have Klan activity, and I was wondering how far away it is?

Blee: Wherever I talk people always think it's their town. That's something that is kind of scary about America, right?

Audience: I was wondering about the process of gaining access. On the one hand your participants were worried that you were with the police, or that you would somehow turn them in, but then once you've crossed some sort of line they do want to talk to you and tell you their story. And then there's the issue of them knowing about your work, and them using you as a voice.

Blee: Yeah, I think the best insight on this came from Andy Warhol: people like their fifteen minutes of fame. It's amazing what people tell you to get that fame. Even when I said "we're not going to talk about anything illegal, nothing you're thinking of, nothing you ever did, nothing anyone else did - I can't protect that legally so we're not going to talk about that," every few minutes some of them would bring something like that up and I'd have to say again "no, we're 
not going to talk about this." It's just amazing. It's very hard to get into these groups - it took me years to get in - but once you are in, people just spill their guts. There's something about having someone hear your story that's exhilarating. Although the barriers of entry are very high, once in, people will talk to you. It is also a gender thing. I don't think a man would have had the same access I did. As a woman, I came across as very unthreatening to these people.

Audience: Can you talk about how people join these groups or are targeted for recruitment?

Blee: In the 1920's the Klan grew very quickly. It took in about 3 to 5 million people - this was a huge part of the population in the 1920's! And it grew so fast because they recruited whole institutions, particularly churches and other civic organizations, at once. Rarely did one person join alone. Whole organizations would join.

Now, today, it's different. If you went out and found a random Klan person they probably would fit your stereotype - isolated, with a bad job, living in a trailer. Someone who has a crummy life who wants to take out their anger on someone. But, description becomes explanation here. You have a description of these people - this is their life - and it slides into an explanation.

To avoid this, I asked people how they got into the group and did a chronology of their life before they joined the group. So instead of looking at them at one point of time I looked at them over time. What I found was that most of them were totally different before they joined their racist group. Most of them had had middle class jobs, most of them had some college or college degrees, they grew up in families that weren't abusive, things like that.

So what happened? They got into these groups for a variety of very serendipitous reasons that almost never have anything to do with the ideology of the group. They start partying with people, they get hooked into a group, they meet people in classes, Bible study - things that have nothing to do with race. Over time they start hanging out with friends of friends, and over time they get pulled into this group. And, over time they come to adopt those ideas. What happens when you are sliding your way into a Nazi group? Well, it doesn't take too long after you have swastika tattoos 
up your arm that your parents say "hit the road buddy!" because how many people want their neo-Nazi son home for Thanksgiving? So, they don't have their family around. Their old friends don't want to hang around them anymore. Their employer doesn't want them there - they get fired. So, over time, politically, socially and economically they slide into marginality. Over time they come to look like our stereotype. But this doesn't explain why they joined the group, this is the product of being in the group. Very mundane reasons bring people to the groups but the outcomes make them into the stereotype.

Audience: Coming back to the issue of anonymity, how do you do work that involves such intimate details of people's lives without it becoming an invasion of privacy?

Blee: I think that is a foundational, ethical problem. As sociologists, especially ethnographic sociologists, what we do is strip away people's privacy. And, we like to tell ourselves that we're not really doing that because we don't use people's names, but that's a thin veil for some very difficult ethical issues. I don't really have an answer for you. In my project on social movements now this is a huge issue because talking to political activists right now when there are more and more constraints or concerns about what use the government might make of those data is really a problem. It is a difficult time to be exposing people - they have less protection.

Audience: How do you deal personally with doing work that gives attention to, or glorifies such negative groups?

Blee: I try not to glorify them. I've spent a lot of time working with anti-racist groups. I try to think about ways in which what I found can have some concrete application. And there's a whole world of anti-racist groups out there. Even in designing this research I worked with anti-racist groups asking "what is it that we don't know that we need to know?" That's the kind of thing I do. What we knew about the racist groups before I did this project was just based on what the leaders said, but not what the individual racist activist are like. You're right, they are difficult questions but a useful dialogue to have. 
Audience: What kinds of reasons did people give you for their racist or anti-Semitic ideologies?

Blee: That's an interesting question. Let me answer it this way. When I talked to these people about what they believe, I would say, for example "well, where did you get all your racist ideas?" or something like that. And almost everyone would say something like, "this big thing happened to me at some point." It would usually be along these lines: "I was in $3^{\text {rd }}$ grade and I had to take a bus to school, and there was this black boy next to me on the bus who always took my lunch — or something — and from that point ever after I realized that black people were evil, or bad, etc.” The interesting thing about that is, first of all, it's a stupid episode they are describing - it wasn't a racial issue at the time, it was a personal thing. Only in retrospect does it seem racial. This shows the deep, underlying racism in the white population, so that for a whole myriad of daily life incidences people can pick and choose from their past to explain their racism.

When I asked people why they were anti-Semitic, however, I got a totally different answer. Remember, these people are deeply anti-Semitic! But when I'd ask where they came to these ideas, they wouldn't have an answer. They'd say nothing happened, they just know Jews are evil. I'd ask them if there were specific Jews they didn't like and they couldn't name any. They don't have any personal reference because most of these people haven't met any Jewish people. Their anti-Semitism is completely created, just a magical secret they learn in racist groups. Their anti-Semitism is the product of the group because there's not a deep enough vein of anti-Semitism in the population as there is with racism.

Audience: Did the members of the group disagree with your analysis of their organization?

Blee: Well, they would disagree with my characterization of their group. They disagreed with my tone of the group, but not with the analysis. There are many racists, so there is probably some variation, but they mostly disagreed with my evaluation of them but not how I described them. 